\section{Cervical intraepithelial neoplasia in postmenopausal women with negative cervical cytology}

Four cases of cervical intraepithelial neoplasia were detected among 50 postmenopausal women in whom cytological examination of a cervical smear yielded negative results, indicating the need for cytological surveillance of women into old age.

\section{Patients, methods, and results}

Cytological and colposcopic examination of the cervix was performed in 50 women presenting to a menopausal clinic with symptoms of the climacteric before they began hormone replacement treatment. The mean (SD) age was 50.38 (4.51) years with a mean postmenopausal time of 31 (33.87) months. No patient was known to have had a previous dyskaryotic smear or a clinically suspicious cervix, and repeat colposcopic and cytological examinations were performed if the patient returned after at least two months' hormone replacement treatment.

The women underwent 101 colposcopic examinations, at which cytological smears were obtained. Initial cytological findings. were negative in all patients. One smear had a suspicious appearance on review, and colposcopy and biopsy confirmed a subclinical papilloma virus infection of the cervix without intraepithelial neoplasia. None of the remaining 49 patients showed cytological abnormalities during the study.

Colposcopic examination in these 49 patients disclosed that $11 \mathrm{had}$ an atypical transformation zone (table). Acetowhite epithelium (in which a

Details of patients with negative results on cytological examination and atypical transformation zone

\begin{tabular}{|c|c|c|c|c|c|}
\hline $\begin{array}{l}\text { Case } \\
\text { No }\end{array}$ & $\underset{\text { (years) }}{\text { Age }}$ & $\begin{array}{l}\text { Duration of } \\
\text { menopause }\end{array}$ & $\begin{array}{c}\text { No of } \\
\text { negative } \\
\text { smears }\end{array}$ & $\begin{array}{l}\text { Colposcopic } \\
\text { findings }\end{array}$ & Histological findings \\
\hline $\begin{array}{l}1 \\
2\end{array}$ & $\begin{array}{l}54 \\
53\end{array}$ & $\begin{array}{l}4 \text { years } \\
4 \text { years }\end{array}$ & $\begin{array}{l}3 \\
3\end{array}$ & $\begin{array}{l}\text { AWE } \\
\text { AWE }\end{array}$ & $\begin{array}{l}\text { CIN II-III } \\
\text { Normal squamous }\end{array}$ \\
\hline $\begin{array}{l}3 \\
4 \\
5+ \\
6\end{array}$ & $\begin{array}{l}52 \\
51 \\
50 \\
50\end{array}$ & $\begin{array}{l}3 \text { months } \\
5 \text { years } \\
9 \text { years } \\
10 \text { years }\end{array}$ & $\begin{array}{l}2^{*} \\
2 \\
2^{*}\end{array}$ & $\begin{array}{l}\text { AWE + mosaic } \\
\text { AWE } \\
A W E+\text { mosaic } \\
\text { AWE }\end{array}$ & $\begin{array}{l}\text { Sguamous metaplasia } \\
\text { CIN I } \\
\text { CIN I } \\
\text { Normal squamous }\end{array}$ \\
\hline 7 & 49 & Irregular & 3 & AWE & $\begin{array}{l}\text { epithelium } \\
\text { Normal squamous }\end{array}$ \\
\hline $\begin{array}{l}8 \\
9\end{array}$ & $\begin{array}{l}49 \\
49\end{array}$ & $\begin{array}{l}3 \text { years } \\
9 \text { months }\end{array}$ & $\begin{array}{l}2 \\
3\end{array}$ & $\begin{array}{c}\text { AWE + punctate } \\
\text { AWE }\end{array}$ & $\begin{array}{l}\text { Squamous metaplasia } \\
\text { Thickened squamous }\end{array}$ \\
\hline 10 & 45 & Irregular & $2^{*}$ & AWE + mosiac & $\begin{array}{l}\text { Inflamed squamous } \\
\text { epithelium }\end{array}$ \\
\hline $\begin{array}{l}11 \\
12\end{array}$ & $\begin{array}{l}37 \\
50\end{array}$ & $\begin{array}{l}6 \text { years } \\
12 \text { years }\end{array}$ & $\begin{array}{l}2 \\
1\end{array}$ & $\begin{array}{c}\text { AWE } \ddagger \\
\text { AWE + punctate }\end{array}$ & CIN II \\
\hline
\end{tabular}

AWE $=$ Acetowhite epithelium. CIN $=$ Cervical intraepithelial neoplasia. Negative smears but classed as inflammatory exudate on one occasion.

tNormal findings on colposcopy at second visit.

white lesion formed on addition of acetic acid) was the predominant feature, but three also had a mosaic pattern, and one had a punctate vascular pattern. Acetowhite epithelium was noted at the first colposcopic examination in 10 patients and was still present in nine at the next examination two to four months later. In the 11th patient (case 5) an inflamed cervix was seen at the first examination, and a McDonald suture, which had been in situ for 19 years, was removed. Two months later, during hormone replacement treatment, an acetowhite lesion was visible. Punch biopsy of all acetowhite epithelia showed benign epithelium in seven patients. In the four others cervical intraepithelial neoplasia was diagnosed (grade $I$ in three cases and grade II-III in one)

One patient not in the study (case 12) presented with postmenopausal bleeding during the course of the study. Cervical cytology yielded negative results, and she had a clinically benign cervix. Colposcopic examination showed an acetowhite lesion, which was confirmed histologically to be cervical intraepithelial neoplasia grade II.

Cervical intraepithelial neoplasia confirmed by biopsy was treated by cone biopsy if the squamocolumnar junction was not visible (cases $1,4,12$ ) and by follow up review if it was visible (cases 5,11 ). Histological and cytological findings were reviewed for evidence of false negative smears. All smears from patients with cervical intraepithelial neoplasia were considered to be negative. Endocervical cells were noted in only two patients. Smears may not, therefore, have been taken from the squamocolumnar junction, but all cervical intraepithelial neoplasms were evident on the ectocervix, from which smears were obtained.

\section{Comment}

Concern has been expressed that mortality from cervical cancer in older women is not falling. ${ }^{1}$ Our finding that $8 \%$ of patients (four out of 50) had cervical intraepithelial neoplasia was unexpected, and the persistent failure of cytological examination to detect these lesions was disturbing, though mild dyskaryosis may be difficult to detect, especially in older women with poor cellular exfoliation. Clearly, few of these cases of mild epithelial abnormality will progress to invasion. Such progression would be slow and could be detected by repeated cytological examination, but not if surveillance is stopped at the age of 60 , as recently suggested by a Canadian task force. ${ }^{2}$ Two negative smears do not appear to preclude cervical intraepithelial neoplasia, but colposcopy and cytology together can greatly improve the diagnosis of cervical abnormality. ${ }^{3}$ Although such screening is not generally practicable at present, it may be the only way of truly eradicating cervical cancer.

We thank Dr M C Anderson for reviewing the histology, and Mrs Zis Willoughby and Dr D M Hart for their help.

1 Husain OAN. Britain's failure to prevent deaths from cervical cancer. Br Med F
$1984 ; 289: 50$.
2 Canadian Task Force. Cervical cancer screening programs: summary of 1982
report. Can Med Assoc J 1982;127:581.
3 Coppleson M, Reid B. Preclinical carcinoma of the cervix uteri: its origin, nature and
management. 1st ed. Oxford: Pergamon Press, 1967:113, 180. (Accepted 18 October 1984)

Departments of Gynaecology and Pathology, Western Infirmary, Glasgow G11 6NT

ANTHONY D G ROBERTS, MB, MRCOG, registrar

RODNEY B DENHOLM, BSC, MB, lecturer

J W CORDINER, MRCOG, FRCS, senior lecturer

Correspondence to: Mr A D G Roberts.

\section{Single dose vitamin $D$ treatment for osteomalacia in the elderly}

Nutritional osteomalacia can be treated effectively by giving small doses of oral vitamin D daily. ${ }^{1}$ Osteomalacia due to irremediable malabsorption may require larger doses ${ }^{1}$ or parenteral treatment. Problems of compliance and malabsorption in the elderly led us to examine the effect of a single depot injection of vitamin $D$ in seven elderly women with osteomalacia.

\section{Patients, methods, and results}

The subjects were aged 75-94; three were long stay patients in hospital, and the others lived at home. Three had had partial gastrectomies. Five of the patients had bone pain and tenderness; the two others were severely demented and their histories were incomplete. All had raised serum alkaline phosphatase activities, six had low serum calcium concentrations (corrected for serum albumin concentration), and three had low serum inorganic phosphate concentrations. Serum 25-hydroxyvitamin D concentrations were less than $12.5 \mathrm{nmol} / \mathrm{l}(5 \mathrm{ng} / \mathrm{ml})$ in all patients.

Each subject was given a single intramuscular injection of $15 \mathrm{mg}$ ergocalciferol (calciferol injection). Serum calcium, inorganic phosphate, and 25-hydroxyvitamin D concentrations and alkaline phosphatase activity were measured at intervals over the next six months and subsequently in three patients (at 12, 15, and 17 months, respectively).

Hypophosphataemia was corrected within one month after treatment and hypocalcaemia within six months in all patients with these conditions. At no time was hypercalcaemia seen. Serum 25-hydroxyvitamin D concentrations rose slowly in all subjects to values consistent with adequate vitamin $D$ nutrition. The highest 25 -hydroxyvitamin D concentration observed was $102 \mathrm{nmol} / 1(40.8 \mathrm{ng} / \mathrm{ml})$, which was in no way comparable with values seen in vitamin $D$ intoxication $(>600 \mathrm{nmol} / 1$ (>240 ng/ml)). The figure shows mean serum concentrations. In each patient serum alkaline phosphatase activity responded to treatment. After six months activity had fallen in five patients and become normal in three of these. In one patien serum alkaline phosphatase activity rose rapidly after treatment, was still high at six months, but had fallen almost to normal at 17 months. In the other the high value persisted for six months but had declined substantially by 15 months without further treatment. Serum concentrations of calcium 
and inorganic phosphate were still normal in the three patients followed up beyond six months. Serum 25-hydroxyvitamin D concentrations were still adequate in each case $(28,85$, and $55 \mathrm{nmol} / 1$ respectively $(11.2,34$, and $22 \mathrm{ng} / \mathrm{ml})$ ).
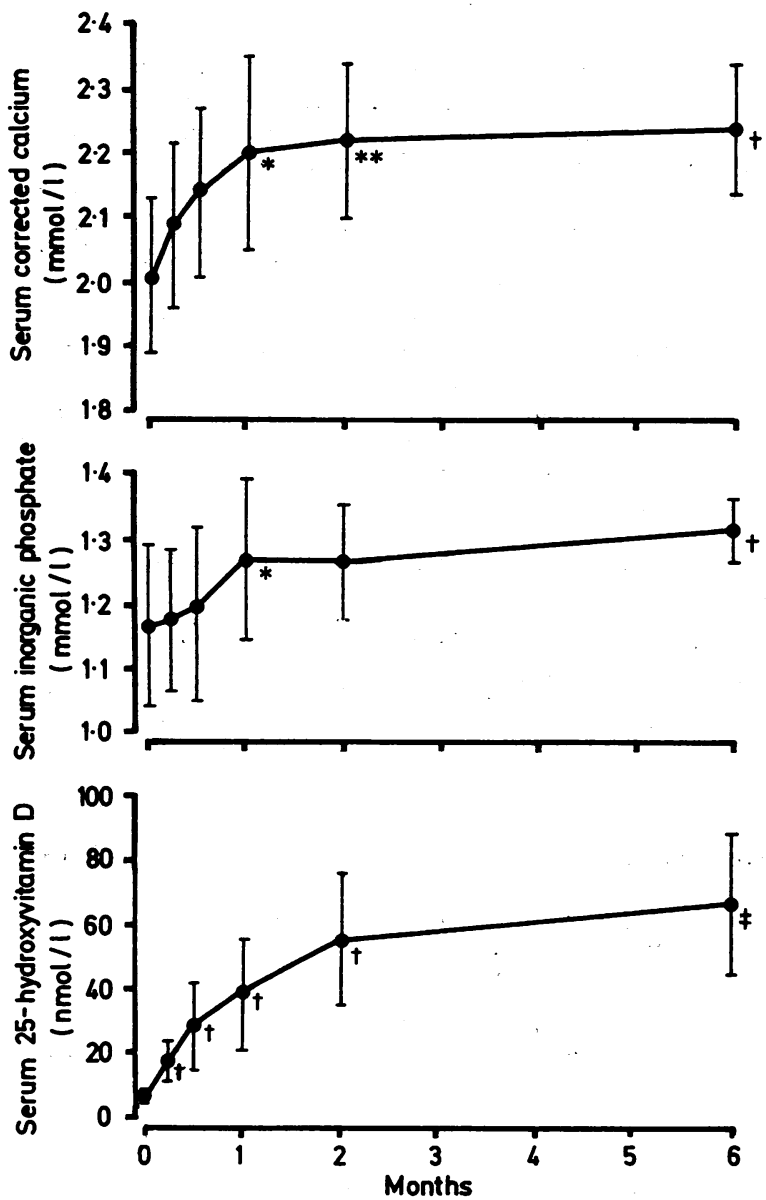

Mean (SD) serum corrected calcium, inorganic phosphate, and 25-hydroxyvitamin $\mathrm{D}$ concentrations before and after $15 \mathrm{mg}$ calciferol intramuscularly. Serum calcium concentration was corrected for serum albumin concentration by the formula : corrected calcium $(\mathrm{mmol} / \mathrm{l})=$ measured calcium $(\mathrm{mmol} / \mathrm{l})+$ 0.023 (40-albumin $(\mathrm{g} / 1)$ ).

Paired $t$ test comparing values before and after treatment: ${ }^{*} p<0.05$; $* * \mathrm{p}<0.02 ; \dagger \mathrm{p}<0.01 ; \ddagger \mathrm{p}<0.001$.

Conversion: SI to traditional units-Corrected calcium: $1 \mathrm{mmol} / 1 \approx 4 \mathrm{mg} /$ $100 \mathrm{ml}$. Inorganic phosphate: $1 \mathrm{mmol} / 1 \approx 3 \mathrm{mg} / 100 \mathrm{ml}$. 25-hydroxyvitamin $D: 1 \mathrm{nmol} / 1 \approx 0.4 \mathrm{ng} / \mathrm{ml}$.

\section{Comment}

The biochemical responses observed in our seven patients were similar to those previously described in treated osteomalacia." We found that a single $15 \mathrm{mg}$ injection of vitamin $D$ was effective in initiating and sustaining healing of osteomalacia for at least six months. In three subjects the single injection ensured adequate serum 25hydroxyvitamin D concentrations for at least a year. As with other vitamin D regimens, subsequent treatment depends on the results of regular biochemical monitoring. The effectiveness of our single dose treatment in increasing 25-hydroxyvitamin D concentrations is comparable with that of single large oral doses of vitamin $D$ in Asian immigrants without osteomalacia.4 Our regimen is safe: no patient developed hypercalcaemia, and concentrations of 25-hydroxyvitamin $D$ remained well below values seen in poisoning with vitamin D. Vitamin D given intramuscularly probably remains at the site of injection and is released slowly into the blood. . $^{2}$

Poor compliance is a problem in elderly people especially in those living at home, as were four of our patients. Patients may already be taking drugs on a regular basis for other ailments, and so a method of treatment that does not require "another bottle of tablets" would be worth while.

We thank the clinicians who referred patients to us and the Tayside Health Board for financial support.
1 Exton-Smith AN. Metabolic bone disease. In: Wright v, ed. Bone and joint disease in the elderly. Edinburgh: Churchill Livingstone, 1983:150-66. 2 Paterson CR, Feely J. Vitamin D metabolites and analogues, diphosphonates, $\mathbb{D}$ danazol, and bromocriptine. Br Med F 1983;286:1625-8. Sharland D. Osteomalacia in the elderly. $\mathcal{F}$ Coll Physicians Lond 1982;16:50-2.C Stephens WP, Klimiuk PS, Berry JL, Mawer EB. Annual high-dose vitamin Dprophylaxis in Asian immigrants. Lancet 1981 ;ii:1199-201.

Whyte MP, Haddad JG Jr, Walters DD, Stamp TCB. Vitamin D bioavailability:

serum 25-hydroxyvitamin D levels in man after oral, subcutaneous, intra-

muscular, and intravenous vitamin D administration. $f$ Clin Endocrinol Metab

(Accepted 1 November 1984)

Department of Biochemical Medicine, Ninewells Hospital, Dundee $\overline{\overline{\overrightarrow{ }}}$ DD1 9SY

J BURNS, MSC, FIMLS, medical laboratory scientific officer

C R PATERSON, DM, FRCPATH, senior lecturer

Correspondence to: $\mathbf{M r} \mathrm{J}$ Burns.

\section{Proliferation of IgD $x$ plasma cells after agranulocytosis induced by dapsone}

Although an excess of lymphoid, plasma, and stromal cells is a known characteristic of bone marrow in idiosyncratic neutropenia induced by drugs, proliferation of monoclonal plasma cells in this disorder has $\infty$ not previously been reported. We report on a patient in whom dapsone $\vec{d}$ caused a reaction with these characteristics and the $M$ component was IgDx.

\section{Case report}

A 52 year old man was admitted to hospital having received dapsone for 30 days for suspected dermatitis herpetiformis. He showed general malaise, had been feverish for the past three weeks, and in the past few days had de- $\vec{\theta}$ veloped tonsillitis and white plaques in the oropharynx. His peripheral blood $\infty$ showed a white cell count of $2.1 \times 10^{9} / 1$, neutrophils $0.12 \times 10^{9} / 1$, haemoglobin concentration $12.6 \mathrm{~g} / \mathrm{dl}$, and platelets $680 \times 10^{\circ} / 1$.

Examination of aspirated bone marrow showed a heavy infiltrate of immature plasma cells, many of them multinucleate and containing Russell $\supset$ bodies and $90 \%$ of them containing intracytoplasmic IgDx when observed by direct immunofluorescence. Promyelocytes were the only myeloid element 0

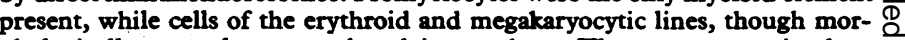
phologically normal, were reduced in numbers. The serum contained an IgD $x$ M component and the urine $x$ chains. Bone studies and studies aimed $O$ specifically at virus antibodies, protozoans, and mycobacteria yielded nega- 3 tive results. The buccal plaques contained Candida albicans. Cutaneous $\supset$ biopsy showed pityriasis lichenoides.

Empirical treatment with antibiotics including antifungal drugs was started. On the eighth day the fever and oropharyngeal disorders abated and signs of myeloid regeneration were observed. After a period of thrombocytosis the peripheral blood counts had returned to normal by the 20th day in hospital. He was found to be asymptomatic and was discharged. On the day $\frac{0}{3}$ before discharge the bone marrow was normal; plasma cells accounted for at most $3 \%$ in all fields and were morphologically normal. Immunoelectro- $O$ phoresis, performed in parallel with the intial sampling, confirmed the dis- 3 appearance of IgD paraprotein from the serum and light $x$ chains from the urine.

\section{Comment}

Idiopathic monoclonal gammopathy is associated with many diseases. It is also found in healthy subjects, some of whom may sub- N sequently develop B lymphocyte disorders, but whether the gammo- $\omega$ pathy is the cause or effect in such cases is not known. In only about $4 \%$ of patients with idiopathic monoclonal gammopathy and another ${ }^{\circ}$ disease does the gammopathy regress at the same time as the associated $\mathbb{D}$ disease, ${ }^{1}$ and this has not previously been reported when the gammo-? pathy has featured IgD as the $M$ component. Furthermore, dyscrasia 0 of plasma cells has been associated with agranulocytosis only once $\stackrel{P}{P}$ before, and in that case it was not possible to prove any cause and $\odot$ effect relation. ${ }^{2}$ So far as we know an increase in monoclonal antibodies $\mathbb{\mathbb { D }}$ in serum as a reaction to agranulocytosis has never been reported.

It is difficult to establish a pathogenic relation between idiosyncratic agranulocytosis induced by dapsone and the proliferation of mono- 8 clonal IgD.3 Although it seems to be well established that B cells bearing IgD have a role in the propagation of immunological memory, the biological role of $\mathrm{IgD}$ in the serum remains controversial. 40 